\title{
THE REFLECTION OF EASTERN PHILOSOPHY IN I. TURGENEV'S NOVEL ON THE EVE
}

\author{
Siwen Guo ${ }^{1, a}$ \\ 1117198, Moscow Miklukho-Maklaya str. 6, \\ Peoples' Friendship University of Russia \\ Moscow, Russia \\ a1316884491@qq.com
}

\begin{abstract}
Keywords: I.Turgenev, Eastern philosophy, religious philosophy, On the eve, Bodhi Tree, Confucianism, Taoism.
\end{abstract}

\begin{abstract}
Despite the fact that at first glance I. Turgenev is not a "writer-philosopher", his work clearly reflects the clash of various philosophical trends of the 19th century. It should be noted that the works of I.Turegenev does not only reflect Western philosophical ideas but also Eastern ones consciously and unconsciously. The purpose of the article is to enrich and perfect the ideology contained in Turgenev's works. In this article, the author studies the novel On the Eve in the contexts of Buddhist canons, Confucianism and Taoism-using historical, analytical, and systematic methods. The author analyzes the philosophical meanings of the Bodhi tree and the problem of its erroneous translation into Chinese. In addition, the article still presents the idea of Chinese classical philosophy in the debates of Shubin and Bersenev. By referring to the research, it can be concluded that from the perspective of accepting aesthetics, the "linden tree" in On the Eve was misinterpreted by Chinese translators as "Bodhi tree", that artificially add color of religious philosophy to the story. The debates of Shubin and Bersenev reflect the profoundness and speculation of Turgenev's novel.
\end{abstract}

\section{Introduction}

Eastern and Western philosophies have two very different origins. Eastern philosophy is the concept of philosophy by regional characteristics. Western philosophy is a unified philosophical system with the same historical tradition and unified conceptual system. The concept of Eastern philosophy does not refer to a philosophical system, but a general term for China, India, Japanese and Islamic philosophy. Chinese philosophy sprouted around the Yin and Zhou Dynasties, and formed in the late Spring and Autumn Period. The Warring States Period witnessed a prosperous era which saw hundreds of schools of thought emerge. In China's feudal society, although religious theology was relatively active, it failed to occupy a dominant position. Confucianism has always been the orthodoxy of Chinese philosophy.

Ancient China experienced a long period of closed-door state. Chinese philosophical elements more or less infiltrated into foreign philosophy and culture. As early as the 16th and 17th centuries, Confucius' theory was introduced into Europe specifically Germany and France, by Jesuits from China. Schelling, a German philosopher, was called "orientalist" by his contemporaries due to his interest in Confucius. Hegel praised the ancient Chinese political system in his book Philosophy of History, even though he denied that he was influenced by Chinese thought. Contrary to Hegel and Schopenhauer who worked at the University of Berlin, they openly admitted that he shared Zhuxi's doctrine and was influenced by Eastern Buddhism. In terms of governing ideas, the influence of Chinese thought is broader. For example, "in the 18th century enlightened autocratic monarch Prussia Frederick II (1712-1786), Russian Catherine II (1729-1796), Austria Maria Theresa (1717-1780) had been directly or indirectly influenced by Chinese political thought" [1].

Russia's study of Chinese philosophy dates back to the 18th century. As early as 1780, the Confucian classic Great Learning was translated into Russian and published. Chinese philosophical thinking and cultural spirit are also reflected in Russian literature. This article takes Turgenev's novel 
On the Eve as an example, using historical, analytical and systematic methods to analyze the Eastern philosophy embodied in the text.

\section{The religious philosophical significance of Bodhi tree}

The beginning of the novel On the Eve by I. Turgenev established that under a high linden tree on the banks of the Moscow River, where the artist Shubin and the philosopher Bersenev held a philosophical dialogue. A linden has two meanings in the Russian-Chinese dictionary - "linden tree" and "Bodhi tree". According to the properties of trees and the climatic conditions of Russia, the tree in the novel On the Eve should be linden tree, and the Chinese literary translators translated it as "Bodhi tree", which adds some religious historical philosophical coloring.

Chinese always confuse the significance of the Linden and the Bodhi tree due to the trees origin. The reason for this confusion is that when Buddhism was introduced to China the followers wanted to plant the Bodhi tree but the Bodhi tree could not grow in the northern regions of China. Monasteries in these regions decided to replace the Bodhi tree with the Linden tree. Even knowing that the tree was of a different origin the monks continued to call the Linden trees Bodhi trees. There are some Linden trees today that are still referenced to Budhi trees throughout China. For example the two "Bodhi trees" in front of Ying Hua Palace in the Gugong Museum [2]. These two trees were planted hundreds of years ago. Replace with - Another example of this confusion was when a Chinese modern writer Lon Yingtai discussed the problem of mistranslation of Bodihi tree in 15th letter "this is not the Bodhi tree" in her correspondence with her son Andre. She found that both the Chinese and the Japanese translated the name of the German song "Der lindenbaum", written by Schubert (1797-1828) in 1827, to the "Bodhi tree", but through her own textual research, it was actually a linden tree. In yet another example, Long Yingtai, a modern Chinese writer mentions the problem of mistranslation of Bodhisattva in his 15th letter Bodhi is not a tree in her correspondence with her son Andre. "Up to now, I do not know whether the translator made a mistake because he did not recognize the linden tree, or because he actually knew it and decided to deliberately misinterpret it for an aesthetic reason. If this song had been translated into linden tree, it would not have been sung by us for 100 years, because the linden tree, a kind of tree that has never been seen and can not be imagined, can not arouse any association in our hearts. But the Bodhi tree is full of meaning and far-sightedness" [3]. Long Yingtai's inference of the intentional incorrect translation is reasonable because the Bodhi tree has a symbolic meaning in the east and the linden tree does not

To explore meanings of the Bodhi tree, we must first talk about its property as a plant. The Bodhi tree (Ficus religiosa) is a large arbor plant of Moraceae and Ficus genus, which grows mostly in the tropics, blooms from March to April, and bear fruits from May to June. It is tall, leafy, and ornamental. Bodhi tree have a very high environmental, economic and medicinal value. The Bodhi tree has many uses; it can purify the air, extract rubber from its milk, and be used for multiple medicinal purposes such as treating asthma, diarrhea, epilepsy, stomach diseases, and so on. Due to its many considerable advantages the Bodhi tree is generally seen as a positive image.

The Bodhi tree has a strong religious color. The word "Bodhi" is a transliteration of the ancient Indian language - Sanskrit "Bodhi", that means awareness and wisdom. Legend has it that more than 2500 years ago Buddha Shakyamuni once sat under a tree for seven nights in search of truth in order to save world. Buddha Shakyamuni eventually conquered all sorts of evil and temptations. It was under this tree that Shakyamuni became the Buddha - the founder of Buddhism, therefore this tree is called Bodhi. Hinduism believes that the Bodhi tree is the place where the Buddha lives, which can make people realize their wishes and free them from guilt.

The significance of the Bodhi tree in Chinese religious philosophy stems from its roots in the Chinese Taoist doctrine. Buddhism began to develop in the Southern and Northern Dynasties (420-589), when the great monk Seng Zhao and Kumarosh from the Western Regions entered Chang'an to give a lecture. In the Sui and Tang Dynasties (581-907), the signification of Buddhism was sinicized. The representatives of Chinese Buddhism are Hui Neng - the six ancestors of Chan Buddhism, and Xuan Zang, the monk in Tang Dynasty of the Consciousness-only School. The poem by Hui Neng "There was no Bodhi tree, and there was no bright mirror. Worldly vanity, nowhere 
pollute", explains the Chinese Buddhism understanding of Bodhi tree. Hui Neng denies the existence of matter, and believes that all things do not exist, only Buddhism exists. His theory belongs to idealism.

The image of the Bodhi tree has a special symbolic meaning in Chinese culture. Chinese translators mistakenly translated the linden tree as a Bodhi tree, that easily evokes associations and resonance among Chinese readers and lays the philosophical tone of the work.

\section{Chinese classical philosophical thoughts in the debate between Shubin and Bersenev}

At the beginning of the novel, the writer described in detail the appearance and gestures of two young men - Shubin and Bersenev. Shubin lay on his chest and looked off into the distance, while Bersenyev lay on his back and looked thoughtfully into the distance. Through different postures of these two men, we can initially suggest that they have different attitudes towards nature. This inference is confirmed during the debate between them. Shubin started asking questions after observing insect which are small, but "how is their life inferior to ours? And why shouldn't they take themselves seriously, if we are to be allowed to take ourselves seriously" [4]. Understanding of the value of human and animal life is one of the basic ideas of Buddhism. According to the idea of Buddhism, "all living beings are equal,". All lives in nature are equal under the law of cause and effect, there is no gap between people and animals. Chinese Buddhism has further expanded the Indian Buddhism's concept of "all living beings are equal", arguing that not only sentient beings are equal, but insensible creatures such as grass, wood, tile, and stone although they have no life they are Buddha in nature. The question raised by Shubin coincides with Buddhist concepts.

Shubin raised such a question because his meticulous observation of nature, thinking about the relationship between man and nature. He knew how to look for deep ideas in the intricacies of nature. Bersenev appreciated nature from another point of view. He seemed to be distracted instead of listening carefully to the question of why he answered, "I was admiring the view. Look how hot and bright those fields are in the sun" [4]. It can be inferred that since the two young persons have different postures they have different viewpoints of nature. Bersenev admired the macroscopic nature at a distance while Shubin observed the microscopic nature of the surroundings. How they looked at nature determines the worldview and their attitudes to the life.

After the above question, they continued to discuss the following topics. The first debate is about beauty. Shubin wrote, the beauty of nature "here there's no form, no finish; it's all over the place" [4]. He admitted that beauty exists in everything, but he was against that a person is busy in pursuit of it because "beauty came down of itself upon their creations from somewhere or other" [4]. From the point of view of Shubin, beauty is quite concrete for example, the beauty of a man's body and the beauty of a woman in sculptural art. Bersenev did not agree with Shubin from his point of view, "If you have no sympathy for beauty, if you do not love beauty wherever you meet it, it will not come to you even in your art" [4]. Bersenev believed that a person should be able to discover beauty at any time and in any place. The second debate is about nature. Shubin thought that nature is dumb because it cannot give an answer only a female heart can give an answer. Nature only awakens the need for love in our hearts, but is unable to satisfy it. Bersenev is full of awe in nature. While admiring nature he is also afraid of the mystery of nature. Because nature breeds life and death at the same time it can stimulate our love and threaten us.

It is not difficult to find that in the dialogue between two young men Turgenev presented us an aesthetics question which is a branch of philosophy. From ancient times to the present and from East to West the interpretation of beauty is complex and changeable. In the history of Western aesthetics, Plato took the lead in exploring aesthetics at a high philosophical level and believed that beauty is not a natural property of the subject. Russian writer Chernyshevsky said that "the beautiful is life". The beginning of Chinese aesthetics is Taoism, which views nature or natural law as beauty. One of the representatives of Taoism Zhuang Zi (about 369-286 BC) first put forward the idea of "the unity of heaven and man". Later in the Han dynasty the thinker Dong Zhongshu developed and turned it into an integral ideological system. 
The meaning of "unity of heaven and man" is that nature and man are closely connected with each other. People's activities should comply with the laws of nature and live in harmony with nature. Zhuang $\mathrm{Zi}$ also said that "the great beauty of heaven and earth cannot be expressed in words" [5]. The Taoist aesthetic idea derived from the epistemology of Lao Zi(about 571-471 BC). Lao Zi believes that before the discovery of the earth there is something that has become the source of all things. This is the so-called "Dao". There are "four big ones" in the universe: people, land, heaven and Dao. According to Laozi, "man follows the laws of the land. Earth follows the laws of heaven. Heaven follows the laws of Dao, and Dao follows itself". Here, heaven and earth mean nature. That is to say, people should firstly respect and conform to nature. In Dao De Jing, Lao Zi wrote that "nature is not benevolent, but also not inhuman. She treats everything as a matter of course" [6]. Taoist theory can explain why Bersenev felt threatened by nature, he felt beauty and love of nature. In fact, Nature is objective and unchanging and the subjective feeling and human psychology is always changed.

The third debate is about love. Shubin strives for hedonistic and egoistical love. He thinks he should be first in line, but Bersenev emphasizes selfless love and puts himself in second place because he considers that "all the meaning of our life." It can be seen that these two men here are talking not only about love but they are also discussing how to treat themselves and others and whether or not they should live for themselves or to live for others. Confucius proposed the idea of philanthropy, as in The Analects of Confucius recorded in the words, "Fan Chi asked about philanthropy, Confucius replied that is loving people" [7]. Then Meng Zi gave further explanations, "humane one love others, and polite ont respect others. The one who loves others, others always love him; who respect others, others always respect him" [8]. Confucianism (Confucius and Meng Zi) defended the view that "there is a difference in love", that means, the degree of love must correspond to the social class and closeness in relations with others. However Mo Zi (c. 476-390 BC), the founder of the Mo school, put forward a new idea of "all-embracing love," which means loving others as much as loving yourself and putting others and yourself on an equal footing. Chinese Buddhism also made its own interpretation of this issue. Buddhism promotes pure altruism, and its core is the idea of "the non-existence of a self, and being useful to others". In conclusion Bersenev's view of love and life is most similar to the Chinese Buddhist idea.

\section{Conclusion}

Analyzing the novel On the Eve we can say that it reflects hidden Eastern philosophical ideas including Buddhism, Taoism, and Confucianism. This result cannot directly prove that the creative work of I. Turgenev is precisely under the influence of Eastern philosophy. An understanding of the philosophical meanings of the novel shows us a new point of view for scientific research, helping to define the topic and in-depth study of the images of the main characters and the content of writer's works. Shubin and Bersenyev think of the world both in Western and Eastern philosophies.

\section{References}

[1] Zhu Qianzhi. The Influence of Chinese Philosophy on Europe, Shanghai: Shanghai People's Publishing, p. 334, 2005.

[2] Zhang Naiwei, Imperial life in the Qing Dynasty. Beijing: Zijincheng Publishing, p. 996, 2009.

[3] Long Yingtai, Andre, Dear Andre. Beijing: People's Publishing, p.115, 2008.

[4] I. Turgenev, Collected works, Moscow: Literature, vol.2, p. 238, 1980.

[5] Zhuang Zi. Zhuang Zi, Beijing: Zhonghua Publishing, p. 910, 1983.

[6] Lao Zi. Dao De Jing, Beijing: Beijing Publishing, p. 13, 2004.

[7] Confucius. Lun Yu, Beijing: Chinese Publishing, p. 131, 1980.

[8] Meng Zi. Meng Zi, Beijing: Chinese Publishing, p. 165, 2007. 